\title{
"Organizational Climate and Job Anxiety of Primary School Teachers with Special Reference to Coimbatore District"
}

\author{
Dr. P. Natarajan, Prathiba $\mathbf{R}$ \\ Associate Professor, PG and Research Department of Social Work, Hindusthan College of Arts and Science \\ Coimbatore, \\ II MSW Student, PG and Research Department of Social Work, Hindusthan College of Arts and Science \\ Coimbatore.
}

\begin{abstract}
:
The number of workloads borne by the teacher will result a negative impact. An organizational climate is crucial because it can generate a comfortable working condition for teachers. Otherwise, an unfavorable organizational climate can impact poor working conditions that affect teachers to experience job Anxiety. This study aimed to determine the effect of workload and organizational climate on the work Anxiety of primary school teachers in Coimbatore. In this study an attempts has been made to find out the relationship between organizational climate and job anxiety of primary school teachers. The sample consisted of 60 teachers selected randomly from various public and private primary schools. A set of tools containing organizational climate and job anxiety was used to gather information. The data were analyzed by t-test and person's coefficient correlation. The results revealed that $(43.3 \%)$ of the respondents are moderate level of organizational climate, $(40 \%)$ of the respondents are good level of organizational climate and $(16.7 \%)$ of the respondents are poor level of organizational climate and $(43.3 \%)$ of the respondents are low level of job anxiety, $(40 \%)$ of the respondents are moderate level of job anxiety and $(17 \%)$ of the respondents are high level of job anxiety.
\end{abstract}

Keywords: Organizational climate, Job anxiety and Teachers.

\section{Introduction}

Schools are a vital constituent of education and schooling systems in each country and play an essential role for both improvement and development of an educational system (Ahghar, 2008). Primary school teachers occupy a crucial position in providing early education. Improving the quality of primary school teachers is very important to prioritize in forming qualified human resources. The teachers are required to play active roles in efforts to fulfill the goals of primary education. Therefore, they must learn various kinds of functions, such as the roles as teacher, model, advisor, authority holder, reformer, guide, executor of routine tasks, visionary person, realistic person, storyteller, researcher, and assessor (Pullias \& Young, 1968). Organizational climate of an educational institution is the product of the relationships between the Head Masters and his staff, between teachers and his students and of the teacher among themselves. Thus, keeping in view the present study is designed to focus on the significance between organizational climate and job anxiety of primary school teachers. The investigator feels that such study would give an insight to teachers and will enhance the performance of the teachers. Better school climate can reduce the teacher's job anxiety. School climate must provide feelings of job security and encouraging environment for teaching free of fear.

\section{Definition}

Halpin and Crafts (1963). Who define climate of the school with reference to the behavior of the teachers and the principals. Good climate helps an individual to keep successfully in the right place. School climate plays a significant role in shaping the citizens of a nation because schools are social institutions.

Srivastva (1985). Anxiety is "employees" predisposition to emotional tension caused by him generalized feelings of vague fear, insecurity and apprehension in respect to one several constituents of his job life. 


\section{Statement of the Problem}

The quality of Education of any nation depends upon the qualities of its schools, which in turn, depends significantly on the qualities of the committed teachers and reduces of job anxiety. The effectiveness and stability of the schools are mostly based on their organizational climate as well as on the satisfaction of the committed teachers and reduces of job anxiety. An organization could be defined as a system that consciously co-ordinates the activities of two or more persons and influences their behavior. The school as an organization has certain aims and objectives which it has to achieve (National Policy on Education 2004). Teaching and learning situation in schools seem to be a function of the atmosphere of the school and the productivity of the teacher. In this school climate teachers has responsibilities, accountabilities and also committed towards their work. Commitment is associated with greater job effort and involvement (Mowday et al., 1979). A school with a positive climate for teachers is more likely to have committed teachers and reduces of job anxiety (Reihl \& Sipple, 1996). Every teacher is expected to be an ideal man with a high moral character. Professionally, he is supposed to have rapport with all persons concerned with his profession. The teachers' commitment to their schools as organizations served.

\section{Scope of the Study:}

Primary schools and teachers have important roles in society for directing the society to the teachers. Recent research suggests that good teaching is a complex undertaking that requires careful planning as well as the capacity to adjust one's performance, according to student responses (Clark \& Peterson, 1986). Bahrami, Mohd. A. et al, (2016), study revealed that Improving the organizational climate could be a valuable strategy for improving organizational commitment and reduces of job anxiety. Jamal (2011) has found in his study that job anxiety and employees' morale as a whole and its components like workload, student misbehavior; classroom resources, poor colleague relation, etc. are predictors of organizational climate. If quality education is the goal, it cannot be achieved without the sincere efforts of dedicated, accountable and committed teacher. It is the committed teachers that can play an important role in educating the future members of a society through their work in schools. The teachers should have accountability, responsibility and commitment towards their job which can only be possible when school climate would be healthy and have harmonious interpersonal relationship. In this context, researcher selected the present problem to study 'Organizational Climate and Job Anxiety of Primary School Teachers". The purpose of this study was to find out those factors which contribute in developing the organizational climate of the teachers and to develop a healthy and reduces of job anxiety.

\section{Review of Literature}

Singh \& Dhawan, (2012). A stressful organizational climate is characterized by limited decision-making participation. Employees are not informed about policies; work activities are limited to routines, use of punishment and negative feedback, no group support, poor relationship with leaders, physical facilities work environment is not managed well. Herefore, a comfortable organizational climate can cause employees to be free from anxiety and improve the quality of work.

Allam and Koteshwar (2005). It is a general psychological fact that the individual becomes anxious more frequently about the work to which he develops a deep concern and is psychologically identified. The new challenges have posed greater job anxiety among all categories of employees working at different level among various types of organizations.

McEvoy (2000). Anxiety is "employees" predisposition to emotional tension caused by him generalized feelings of vague fear, insecurity and apprehension in respect to one several constituents of his job life. People's life in existing civilization has happen to more diversely challenging, complex, unthinking and dependent, is running by the clock.

\section{Methodology of the Study \\ Objectives of the Study}

- To find out personal profile of the respondents. 
- To assess the level of organizational climate and job anxiety of primary school teachers.

- To find out association between personal profiles and organizational climate and job anxiety of primary school teachers.

- To find out the relationship between personal profile and organizational climate and job anxiety of primary school teachers.

- To valuable suggestion about organizational climate and job anxiety of primary school teachers.

Research design: 'Descriptive research design Method of Research' was adopted to conduct the present study.

Universe of the study: The universe of the current examination is the Coimbatore district.

Sampling: 60 primary school teachers were selected using simple random method from Coimbatore city of Tamil Nadu- INDIA. The selected teachers were working in public and private primary schools.

Tools for data collection: 1.Organizational Climate Description Questionnaire by Motilal Sharma (1978) was used to measure the School Organizational Climate. It consists of 64 statements and 8 sub areas. Higher the score on this scale indicates higher the organizational climate. The scale was found to have a reliability ranging from .34 to .81 and a validity of scale is 63 .

2. Job Anxiety scale developed by Srivastava, A.K. (1977) was used to measure the job anxiety. It has 80 statements and $7 \mathrm{sub}$ areas namely, security, recognition, human relation at work, reward and punishment, self esteem, future prospects, and capacity to work. Higher the score on this scale indicates higher the job anxiety. The test-retest reliability of scale is.81.

Statistical tools: The following statistical techniques were used to analysis the data.

$>$ Simple test

$>$ t-test

$>$ ANOVA

$>$ Pearson's coefficient of correlation.

Finds of the Study

\begin{tabular}{|c|c|c|c|}
\hline Factors & MEDIUM & FREQUENCY & PERCENT \\
\hline Age & $36-50$ & 26 & $43 \%$ \\
\hline Gender & Female & 38 & $63 \%$ \\
\hline Type of family & Nuclear & 28 & $47 \%$ \\
\hline Community & BC & 32 & $53 \%$ \\
\hline Monthly income & Rs.35001-Rs.60000 & 27 & $45 \%$ \\
\hline Educational & M.sc., B.Ed. & 37 & $60 \%$ \\
Qualification & & & $58 \%$ \\
\hline Years of experience & $15-25$ & 35 & \\
\hline
\end{tabular}

\section{Simple Percentage Analysis}

$\checkmark \quad$ Less than half (43\%) of the respondents is in the age group between 26-30 years.

$\checkmark \quad$ More than half (63\%) of the respondents are female.

$\checkmark \quad$ Less than half (47\%) of the respondents is in the nuclear type of family.

$\checkmark \quad$ Nearly (53\%) of the respondents are BC Community.

$\checkmark \quad$ Less than half (45\%) of the respondents are monthly income Rs. 35001-60000.

$\checkmark \quad$ More than half $(60 \%)$ of the respondents are M.Sc,. B.Ed. of educational qualification.

$\checkmark \quad$ Nearly (58\%) of the respondents are 15-25 years of experience.

Distribution Of The Respondents By Level Of Organizational Climate Of Primary School Teachers 


\begin{tabular}{|c|c|c|c|}
\hline S. No & $\begin{array}{c}\text { Organizational } \\
\text { Climate }\end{array}$ & No. of Respondents & Percentage (\%) \\
\hline 1 & Good & 24 & 40.0 \\
\hline 2 & Moderate & 26 & 43.3 \\
\hline 3 & Poor & 10 & 16.7 \\
\hline \multicolumn{2}{|c|}{ TOTAL } & $\mathbf{6 0}$ & $\mathbf{1 0 0}$ \\
\hline
\end{tabular}

\section{Interpretation}

The above table depicts that (43.3\%) of the respondents are moderate level of organizational climate, $(40 \%)$ of the respondents are good level of organizational climate and (16.7\%) of the respondents are poor level of organizational climate.

Distribution of The Respondents By Level Of Job Anxiety Of Primary School Teachers

\begin{tabular}{|c|c|c|c|}
\hline S. No & Job Anxiety & No. of Respondents & Percentage (\%) \\
\hline 1 & High & 10 & 17.0 \\
\hline 2 & Moderate & 24 & 40.0 \\
\hline 3 & Low & 26 & 43.0 \\
\hline \multicolumn{2}{|c|}{ TOTAL } & $\mathbf{6 0}$ & $\mathbf{1 0 0}$ \\
\hline
\end{tabular}

\section{Interpretation}

The above table depicts that $(43.3 \%)$ of the respondents are low level of job anxiety, $(40 \%)$ of the respondents are moderate level of job anxiety and $(17 \%)$ of the respondents are high level of job anxiety.

Influence of Personal Profile and level of Organizational Climate and Job Anxiety of Primary School Teachers.

\begin{tabular}{|l|c|c|c|}
\hline \multicolumn{1}{|c|}{ Variables } & $\begin{array}{c}\text { Statistical } \\
\text { tool }\end{array}$ & Value & Result \\
\hline Age and Organizational Climate & ANOVA & $\begin{array}{c}\mathrm{F}=.040 \\
\mathrm{~T}<0.05\end{array}$ & Significant \\
\hline Gender and Organizational Climate & $\mathrm{t}$-test & $\begin{array}{c}\mathrm{t}=1.051 \\
\mathrm{p}>0.05\end{array}$ & Not-Significant \\
\hline Type of family and Organizational & ANOVA & $\mathrm{F}=.000$ & Significant \\
Climate & & $\mathrm{T}<0.05$ & \\
\hline Community and Organizational & t-test & $\mathrm{t}=.050$ & Significant \\
Climate & & $\mathrm{p}<0.05$ & \\
\hline Educational Qualification and & ANOVA & $\mathrm{F}=.353$ & Not-Significant \\
Organizational Climate & & $\mathrm{P}>0.05$ & \\
\hline Income and Organizational Climate & ANOVA & $\mathrm{F}=.943$ & Not-Significant \\
\end{tabular}

There is significant difference in the age and organizational climate among primary school teachers.

There is no significant difference in the gender and organizational climate among primary school teachers. 
There is significant difference in the type of family and organizational climate among primary school teachers.

There is significant difference in the community and organizational climate among primary school teachers.

There is no significant difference in the educational qualification and organizational climate among primary school teachers.

There is no significant difference in the income and organizational climate among primary school teachers.

Correlation Table Showing Relationship Between Personal Profile And Level Of Organizational Climate And Job Anxiety

\begin{tabular}{|c|c|c|c|c|c|}
\hline & Age & Gender & $\begin{array}{c}\text { Education } \\
\text { qualification }\end{array}$ & $\begin{array}{c}\text { Organizational } \\
\text { Climate }\end{array}$ & Job Anxiety \\
\hline $\begin{array}{l}\text { Age } \\
\text { Pearson } \\
\text { Correlation } \\
\text { Sig.(2 tailed)N }\end{array}$ & 1 & .005 & -.019 & -.146 & .001 \\
\hline $\begin{array}{l}\text { Gender } \\
\text { Pearson } \\
\text { Correlation } \\
\text { Sig.(2 tailed)N }\end{array}$ & .005 & 1 & -.046 & $-.393^{* *}$ & $-.296^{*}$ \\
\hline $\begin{array}{l}\text { Education } \\
\text { qualification } \\
\text { Pearson } \\
\text { Correlation } \\
\text { Sig.(2 tailed)N }\end{array}$ & -.019 & -.046 & 1 & .087 & .194 \\
\hline $\begin{array}{l}\text { Organizational } \\
\text { Climate } \\
\text { Pearson } \\
\text { Correlation } \\
\text { Sig.(2 tailed)N }\end{array}$ & -.146 & $-.393^{* *}$ & .087 & 1 & $.256^{*}$ \\
\hline $\begin{array}{l}\text { Job Anxiety } \\
\text { Pearson } \\
\text { Correlation } \\
\text { Sig.(2 tailed)N }\end{array}$ & .001 & $-.296^{*}$ & .194 & $.256^{*}$ & 1.000 \\
\hline
\end{tabular}

\section{*Correlation is significant at the 0.05 level (2-tailed).}

**Correlation is significant at the 0.01 level (2-tailed).

$>$ There is significant relationship between the gender and organizational climate of the respondents.

$>$ There is significant relationship between the gender and level of job anxiety of the respondents.

$>$ There is significant relationship between the organizational climate and gender of the respondents.

$>$ There is significant relationship between the organizational climate and level of job anxiety of the respondents. 
$>$ There is significant relationship between the level of job anxiety and gender of the respondents.

$>$ There is significant relationship between the level of job anxiety and organizational climate of the respondents.

\section{Recommendations}

Organizational climate is found to be the best predictor of teacher's job anxiety.

$>$ Thus all possible efforts should be made to keep the organizational climate congenial and soothing to help the teachers to work in a more professional manner.

Apply cultural competence and promote social justice in in-service teacher training programmes.

$>$ A code of behavior and professional ethics may guide teachers by which they carry out their duties. It includes good citizenship, dress code and the teacher's ability to interact with others and society at large.

$>$ In order to increase the level of professional organizational climate and professional responsibility school teachers the educational planner and administrator should keep in their for an educational program.

Teachers should be willing to understand the local community and participate in various activities related to the development of the school and the community also is able to internalize the value of their own day to day world in developing in a rich human resource for the advancement of the individual learner, family, local community and the larger society.

Professionalism, enhancing the knowledge, knowledge refers to the content knowledge, the technical knowledge and practical understanding a teacher needs in order to carry out their duties.

The teachers should always try to identify themselves with their profession and it should be considered as an inseparable.

\section{Conclusion}

This study exemplifies empirical evidence that a good organizational climate will have a direct impact on low job anxiety. A healthy organizational climate will have an immediate effect on high work commitment. Teachers must experience an intense workload and a healthy organizational climate to reduce job anxiety, increase work productivity, and maintain teacher professionalism. This study has a limitation because it only applies independent variables in the form of teacher external factors. Further researchers need to have more attention to internal factors unavailable in this study, such as self-regulation, hardiness, self efficacy, selfcontrol, emotional intelligence, and other internal factors. The results revealed that $(43.3 \%)$ of the respondents are moderate level of organizational climate, $(40 \%)$ of the respondents are good level of organizational climate and $(16.7 \%)$ of the respondents are poor level of organizational climate and $(43.3 \%)$ of the respondents are low level of job anxiety, (40\%) of the respondents are moderate level of job anxiety and (17\%) of the respondents are high level of job anxiety.

\section{References}

1. Allam, Z. and Koteshwar.V.B, 2005. Job anxiety among project managers, Journal of Edutracks Vol $52(3) \cdot 27-30$

2. Amruth, G. K, 2010. A study on group differences in therelationship between organizational climate perception and teaching competence of primary school teachers. Online available sources, files.eric.ed.gov/fulltext/ED510279.pdf.

3. Getzels, J. W and Guba. E. G. 1957. The School Review, Vol.65, No. 4 423-441.

4. Halpin, A.W and Cfaft 1983. The organizational climate of schools, Chicago, Mid West, Administration, Center. TheUniversity of Chicago.

5. Milner, K and Khoza. H, 2008. A comparison of teacher stress and school climate across schools with different matric success rates, South African journal of education, Vol 28. Pp. 155-173. 
6. Sergiovanni, T.J., and Starratt, R.J. 2007. Supervision: A redefinition (8th Ed.). New York: McGraw Hill.

7. Singh.P, Mohanty.M, 1996. Role efficacy in relation to job anxiety and job status, Psycho-lingua, Vol 26. No 1. Pp.25- 28. (Psycholinguistic Association of India, Raipur, INDE).

8. Srivastava.A.K, 1985. Moderating effect of $\mathrm{n}$ Ach, on role stress job anxiety relationship, Psychological studies, Vol 30, No. 2. Pp. 102-106, (Psyc INFO Database record 2012 \APA).

9. Zahoor Z, 2012. A study of organizational climate and adjustment among private and government school teachers, golden research thoughts, Vol 1. Issue: 12. ISSN No:22315063. 